\title{
The Application of Modern Apprenticeship in the Major of Stomatological Technology in Higher Vocational Colleges
}

\author{
$\mathrm{Na} \mathrm{Li}{ }^{1, \mathrm{a}, *}$ \\ ${ }^{1}$ Binzhou Polytechnic, Binzhou 256600, China \\ a951011580@qq.com
}

Keywords: Modern apprentice system; Higher vocational colleges; Stomatological technology

\begin{abstract}
In recent years, education has become the focus of social attention, especially the higher vocational education. Viewed from the current situation of our country's economy development level and the demand of higher vocational students, employment rate of higher vocational colleges is higher than that of ordinary universities, but higher vocational students' post docking ability can't satisfy the needs of modern enterprise. In order to improve the jobs and docking capability of graduates from stomatological education, we need to establish relations of cooperation between enterprises and colleges and universities based on the rule of modern apprenticeship and to help more students to improve their working abilities in employment, with promoting the professional employment ability as the talent cultivation goal of oral medicine vocational education, thus effectively solve the problem of post docking.
\end{abstract}

\section{Introduction}

Apprenticeship is a form of professional education, which has a long history. In essence, modern apprenticeship is a combination of modern vocational education mode and traditional apprentice education mode, and the system has realized the combination of both enterprises and colleges by fostering the talents under the cooperation of both sides. The goal of school talents training and cultivation is to train practical talents, so that students can get the chance to study real post knowledge in a specific work environment. The prominent characteristics of apprentice vocational education is to cultivate high-quality technical talents.

In the application of modern apprenticeship, some specific problems need to be taken into consideration, and the training mode of personnel should be selected according to the corresponding characteristics of vocational colleges. In the field of oral medical technology, it is important to fully analyze the particularity of the specialty and realize the effective combination between the two. The application of modern apprenticeship to college of oral medical technology is in accordance with the principle of talent cultivation.

\section{Training Target of Modern Apprenticeship in Oral Medicine Technology}

In the process of applying modern apprenticeship to oral medical technology education, we must ensure that the modern apprenticeship conforms to the technical college talents training targets. The goal of oral medical technical talents training in vocational colleges can be summarized as: "to make the students master the theoretical knowledge in a comprehensive and systematic way; to equip students with the corresponding practical ability for specific jobs; to cultivate technology talents with all-round development abilities ". There are two types of courses offered in the college of oral medical technology: specialized courses and public basic courses. Among them, public basic courses include politics, computers and college English. The specialized courses include the production of fixed denture, the production of the partial denture, and the making of full teeth. Theory is the basis of practice, so students mastering solid theoretical knowledge can better accomplish practical tasks. Therefore, it is necessary for students in the stomatological technology college to learn relevant professional knowledge well. 


\section{The Application of Modern Apprenticeship in the Specialty of Oral Medicine in Higher Vocational Colleges Based on Employment-oriented Connotation}

New Connotation of Employment Orientation. The file <several opinions on deepening the reform of higher vocational education based on education from the ministry of education (teach high [2004] no. I) > points out: the vocational colleges should fundamentally improve the level of education services, making train practical talent as a fundamental goal. After the file was put forward, all the stomatological vocational colleges have been responding to the requirement of it. They improve their school education strength by setting employment as talent cultivation goal. In addition, graduate employment problem has received wide attention of many researchers, who has made outstanding contributions to improve graduate jobs docking problem.

Particularity of Oral Medical Technology Specialty. The professional requirement of oral medical technology for students is very high. The specific performance is: students learning this major not only have to master the comprehensive and systematic theoretical knowledge, but also has strong practical ability and position and docking capability. Oral medical technology students should learn the content of the denture production and maintenance. Since the produced denture is to taken to the mouth, the demand for the skills of producers in this factory is very high. They need to be equipped with not only professional knowledge, but also professional ability and certain professional qualities.

Reflections on Modern Apprenticeship System. Traditional form of education have certain kinds of limitation, which mainly reflect in the following aspects: the school courses there are irrational; the teachers' teaching ability is relatively low; the theoretical knowledge of students is not comprehensive; their practical ability is relatively low and does not conform to the market demand.

The practice of modern apprenticeship was first put into practice in 2015. The general office of the ministry of education selected pilot units to study and analyze the practice of the modern apprenticeship system. This system has realized the combination of both enterprises and colleges. Personnel training goal in schools of such kind is to train practical talents, so that the students can study to do real work under specific work environment. The prominent characteristics of apprenticeship vocational education is to cultivate high-quality technical talents.

\section{The Constructive Strategies of Vocational Talent Cultivation Mode of Stomatology Major Students Based on Employment-oriented Principle}

In-depth Cooperation between the School and Enterprise. The difficulty of oral medical technical personnel getting employed can be solved in a dual educational way, which is to strengthen the mutual cooperation between oral medical colleges and universities and large production units, and establish a dual education leading group responsible for market research work on oral medical technical talents demand. According to the results of market research, we should adjust the educational goals of colleges and universities to cultivate professional technical talents who meet the needs of the market. The school should also pay attention to the combination of theory and practice in the teaching process, and cultivate students' operating ability, which will run through the teaching process. It is also suggested that schoolwork closely together with the employers to decide the school personnel training plan. They can work together to promote the improvement of the oral medicine education system, bring change to school curriculum structure, choose and open the school specialized courses that conform with the characteristics of school and the needs of employing companies. At the same time, we should improve the faculty of the school and build a professional team with outstanding abilities. The evaluation system of the school should also be improved, and the scientific and reasonable evaluation system should be established, so as to cultivate high quality professional and technical employers.

Optimize Curriculum System and Reorganize Course Content. Compared with traditional talent cultivation mode, modern apprenticeship pays more attention to the importance of practice, and effectively realizes the combination of theory and practice. In the courses offered by the school, 
the proportion of practical courses has been added, and the corresponding positions are provided for the students in the school, so that the theory can be applied to the practice when doing a real job. Each practice course has a corresponding points, only when the students practical courses have been done according to relevant requirements can they obtain the corresponding credits. In the concrete operation of practical courses they often need the guidance of professional people. Under normal circumstances, students learn over a half of the overall courses through practical courses. Schools can open practical courses through the cooperation with related companies in denture production because it will ensure that students receive professional guidance in practice and put effective theoretical knowledge into practice. As a result, students will learn at school professional skills of denture making. The modern apprenticeship requires the amount and content of the course should be adjusted according to the specific situation so as to better play to the role of the vocational skill course. At the same time we can also increase the involvement of the relevant enterprises to professional teaching in oral medicine technology, and adjust course settings according to the actual teaching situation. For example, there is a course called fixed denture technology in dental professional teaching, where teachers can introduce the practical cases in the process of teaching, show students the fixed denture technology through practical operation process, and make it more intuitive. The effect obtained is also very significant. In addition to professional compulsory courses, schools can also set up optional courses. For instance, oral craft aesthetics can be opened as elective courses, and the assessment is conducted separately. The knowledge is for the future work of the students, and to a large extent, it has improved the ability of students.

The modern apprenticeship system pays more attention to the construction of faculty in practice. Teachers are the source of theoretical knowledge of students and serve as the evangelist in education, so the level of teachers has a direct impact on students' learning. College teachers focus on the study of professional knowledge, which leads to the one- sidedness of the students' knowledge. Therefore, the school must adjust the curriculum structure, strengthen the practical ability of teachers, and cultivate the "double teacher" teams.

Flexible and Variable Learning Style. Mentoring relationship has been playing a key role in the smooth development of modern apprenticeship system. If the school can establish a flexible and variable teaching mode and learning mode, students can better master the professional skills taught by teachers. The school can also arrange students to be interns in the cooperated companies, and test the students' professional skills and levels in practice.

In order to apply modern apprenticeship to the major of stomatology, it is necessary for the professional technicians of the denture processing enterprises to cooperate with the teachers of the school. First, denture processing enterprise technicians, as the important force in the talent training process, need to get more professional training and learn more about the requirements for the relevant professional trainers. The guidance of teachers should be joined into the training practice to get more in-depth understanding of professional training goals and to improve their teaching ability. Second, the school selects representatives and sends them to the denture production enterprises to conduct professional operations and learn relevant practical skills. The company should also set up a perfect reward system to establish a perfect teacher evaluation mechanism. In addition, the students' assessment criteria should be specified. According to different indexes, they can receive specific kinds of rewards and punishment. To make it concrete, those who meet the assessment criteria should be awarded, while those who do not meet the assessment criteria should receive punishment.

\section{Conclusion}

Compared with the traditional teaching mode, the modern apprenticeship model has outstanding advantages. It is very important to improve the professional quality of oral medical technology, because it embodies the innovative spirit of teaching model. From the current development level of the modern apprenticeship system, we can see that there are still some shortcomings, which need to be further improved. This paper analyzes the application of modern apprenticeship training mode in oral medicine technology education, and puts forward a dual educational system. The teaching 
mode based on modern apprenticeship will be widely used in the future, and will become the guiding goal of education of higher vocational profession, and become an important way to train professional and technical talents.

\section{Reference}

[1] Zheng Weiqin. Research on the Talent Cultivation Model of the Modern Apprenticeship System for the Employment of Education in Oral Profession [J]. Business Sentiment, 2016, (51): 206.

[2] Zhao Jianming. A Discussion on the Training Mode of Modern Apprenticeship Training in Oral Medicine Technology of Higher Vocational College. [J]. Technical Innovation Guide, 2014, 14(13):217-218.

[3] Yang Xuelong, Chen Hairui. Exploration of Talent Cultivation Mode of Modern Apprenticeships -- by Example of College Oral Medicine Technology [J]. Speed Reading (middle), 2017, (7):65. 